\title{
The Art of Preventive Medicine: How can we Improve our Immune System and Help our Cells Keep their Order in our Body so we can Stay Healthy and Live Long and Happy Lives?
}

\section{Søren Ventegodt MD}

MMedSci, EU-MSc-CAM,Director, Quality of Life Research Center, Research Clinic for Holistic Medicine, Nordic School of Holistic Medicine, Denmark

${ }^{*}$ Corresponding author: Søren Ventegodt MD, MMedSci, EU-MSc-CAM, Director, Quality of Life Research Center, Research Clinic for Holistic Medicine, Nordic School of Holistic Medicine, Denmark, Tel: +45 206667 66; E-mail: ventegodt@livskvalitet.org

Rec date: Mar 06, 2015; Acc date: Mar 09, 2015; Pub date: Mar 12, 2015

Copyright: ( 2015: Ventegodt MD. This is an open-access article distributed under the terms of the Creative Commons Attribution License, which permits unrestricted use, distribution and reproduction in any medium, provided the original author and source are credited.

\section{Editorial}

Everybody wants to stay healthy and yet every second citizen in Denmark and the rest of our modern, rich, western world suffers from a chronic disease [1]. In spite of growing yearly consumption of pharmaceutical drugs the number of chronic patients is pretty constant. Today more than $40 \%$ percent of the population takes pharmaceutical drugs on a regular basis [2].

We therefore know for sure that pharmaceutical drugs are not the general solution to our modern health problems. It is also clear that drugs cannot keep us healthy. Not even the simplest influenza vaccines seem to work effectively; according to recent metaanalyses they only help one in 100 or so [3].

So how can we improve our immune system and help our cells keep their order in our body so we can stay healthy and live long and happy lives?

Interestingly almost all premodern cultures have a strong focus on preventive medicine. The Native Americans form northern America have been thoroughly studied both by doctors and anthropologists $[4,5]$; the conclusion have been these cultures believe strongly in the health-improving effect of rituals that increases your self-knowledge and self-awareness: these rituals often includes the use of hallucinogenic plants like the cactus Peyote and San Pedro, "magical" Psilosybe mushrooms, Datura Stramoni plants etc.; but quite often the rituals are just pushing the participants to go beyond the daily and well-known world and into the unconscious and unknown, like the sweat lodge, the sun dance ritual, hanging from trees in meet hooks etc.

I spite of these rituals obviously being hard and exhausting for the participants, the experts studying them have often concluded that the people participating in such rituals are actually very much helped in keeping their bodies strong and healthy and their minds powerful, active, engaged, clear and happy.

Native people in Middle and South America, Africa, Asia, Australia, Northern Europe and Siberia all seem to have similar rituals with a similar experiential content in spite of differences in style; most cultures have non-drug rituals and rituals which includes the use of strong mind expanding (LSD-like) drugs (i.e. Ibogain, Ayahuasca, Red Amanita etc). To the researchers surprise these rituals almost always carry the tribe's local name for "medicine".

The important question one must ask here is what this premodern medicin really is about in its core? It is obvious that many young people in our western culture take drugs but this does not seem to cure their physical or mental diseases; and many modern people participate in extreme and strenuous activities like Iron Man sports, extreme mountain climbing and skiing etc. but they still fall ill.

So what is it in the native rituals that helps people to stay healthy and even cures disease when it is not the drugs or the activities in themselves?

One researcher fell incidentally over the answer: Aaron Antonovsky $[6,7]$. He studied survivors from the Nazi death camps after World War II, and interviewed hundreds of women who had survived the most horrible of traumas: Some had lost their whole family including their children, some had been beaten, humiliated, raped, and abused in all kinds of ways, and some have almost starved to death. Yet one out of three lived a good life 20 years after or so, while two third of the women was physically and/or mentally ill.

While everybody else focused on the sick women, Antonovsky focused on the healthy and happy ones. He found it truly amazing that some people obviously can heal from even the worst of circumstances and traumas.

As he continued to dig deeper into the personal stories of these women he little by little discovered the blessed path that took the women to healing and health: If you clear yourself of all believes, so you stay empty and free in your mind, you will surface and be healthy and happy again after a while. You need to confront all the feelings you have without judging them; then you need to contemplate on what happened to you until it is clear what happened and how you reacted what you learned so to speak - and then you need to let of your negative ideas and believes. And then you are free, empty, whole and happy again. Salutogenesis, he called it.

And that is precisely what the native people are doing in their rituals: feeling their feelings, exploring their present reality and their past thoroughly and honestly and finally searching for what is true and what is not.

If you go to the old Hippocratic medicine [8] 2400 years ago, you will see that this is also exactly what this medicine is about. This is why European non-drug medicine with talk- and touch therapy was so effective an popular for more than 2200 years, until modern drug companies and scientific institutions and med schools took medicine over, a century or two ago.

The conclusion is that medicine, good old medicine, is here to stay.

New, modern, scientific medicine based on chemistry has proven itself ineffective and also highly dangerous $[9,10]$.

We need to go back to the roots of medicine, to find the healing and preventive power of medicine. The wonderful thing is that this medicine during the last three decades has been proven highly 
Citation: Ventegodt MD (2015) The Art of Preventive Medicine: How can we Improve our Immune System and Help our Cells Keep their Order in our Body so we can Stay Healthy and Live Long and Happy Lives?. Altern Integr Med 4: e115.doi:10.4172/2327-5162.1000e115

Page 2 of 2

effective for most clinical conditions and also completely safe to use in lots of good studies [11-16].

Yes, we can help our patients - but only when we truly understand what healing is about.

\section{Acknowledgments}

The Danish Quality of Life Survey, Quality of Life Research Center and The Research Clinic for Holistic Medicine, Copenhagen, was from 1987 till today supported by grants from the 1991 Pharmacy Foundation, the Goodwill-fonden, the JL-Foundation, E. Danielsen and Wife's Foundation, Emmerick Meyer's Trust, the FrimodtHeineken Foundation, the Hede Nielsen Family Foundation, Petrus Andersens Fond, Wholesaler C.P. Frederiksens Study Trust, Else \& Mogens Wedell-Wedellsborg's Foundation and IMK Almene Fond. The research in quality of life and scientific complementary and holistic medicine was approved by the Copenhagen Scientific Ethical Committee under the numbers (KF)V. 100.1762-90, (KF)V. 100.2123/91, (KF)V. 01-502/93, (KF)V. 01-026/97, (KF)V. 01-162/97, (KF)V. 01-198/97 and further correspondence. We declare no conflict of interest.

\section{References}

1. Kjøller M, Juel K, Kamper-Jørgensen F (2007) Folkesundhedsrapporten Danmark Copenhagen: Statens Inst Folkesundhed.

2. Danmarks Statistik (2010) Forbrug af medicin fordelt efter terapeutiske hovedgrupper. Copenhagen: Danmarks Statistik.

3. Jefferson T, Di Pietrantonj C, Rivetti A, Bawazeer GA, Al-Ansary LA, et al. (2014) Vaccines for preventing influenza in healthy adults. Cochrane Database Syst Rev.
4. Anderson EF Peyote (1996) The divine cactus. Tucson, AZ: Univ Arizona Press.

5. Castaneda C (1968) The teachings of Don Juan: A yaqui way of knowledge. New York.

6. Antonovsky A (1985) Health, stress and coping. London, Jossey-Bass.

7. Antonovsky A (1987) Unravelling the mystery of health. How people manage stress and stay well. San Francisco: Jossey-Bass.

8. www.encyclopedia.com $>$ People $>$ Medicine $>$ Medicine: Biographies.

9. Gøtzsche PC (2014) Psychiatry has gone astray We would be much better off if we took away all psychotropic drugs from the market, The physicians are not able to handle them.

10. Gøtzsche P. (2013) Deadly Medicines and Organised Crime: How Big Pharma Has Corrupted Healthcare, New York.

11. Ventegodt S, Merrick J (2012) Textbook on Evidence-Based Holistic Mind-Body Medicine: Basic Philosophy and Ethics of Traditional Hippocratic Medicine, New York: Nova Science.

12. Ventegodt S, Merrick J (2012) Textbook on Evidence-Based Holistic Mind-Body Medicine: Basic Principles of Healing in Traditional Hippocratic Medicine, New York: Nova Science.

13. Ventegodt S, Merrick J (2012) Textbook on Evidence-Based Holistic Mind-Body Medicine: Healing the mind in Traditional Hippocratic Medicine, New York: Nova Science.

14. Ventegodt S, Merrick J (2013) Textbook on Evidence-Based Holistic Mind-Body Medicine: Holistic Practice of Traditional Hippocratic Medicine, New York: Nova Science.

15. Ventegodt S, Merrick J (2013) Textbook on Evidence-Based Holistic Mind-Body Medicine: Research, Philosophy, Economy and Politics of Traditional Hippocratic Medicine, New York: Nova Science.

16. Ventegodt S, Merrick J (2013) Textbook on Evidence-Based Holistic Mind-Body Medicine: Sexology and Traditional Hippocratic Medicine, New York: Nova Science. 